\title{
Rethinking Teacher In-service Education: The Importance of Shifting to a Professional Learning Community in the Dominican Republic (DR)
}

\author{
Elena A. Dominguez C. \\ INICIA Educación \\ Dominican Republic
}

\begin{abstract}
The Dominican educational system has conventionally adopted fragmented and decontextualized workshops delivered by external entities as its in-service teacher education model. Although teachers are required to participate in those traditional modules annually, international reviews of the Dominican educational system show that traditional teacher professional development (TPD) workshops have not improved teaching and learning in the Dominican context [35], [48]. Moreover, research more broadly indicates that traditional TPD is an ineffective vehicle to promote teachers' learning and professional improvement [45] [50]. However, a growing body of TPD research directly links teacher professional growth and continual learning to collaborative activities that occur in the classroom and school context [44], [51]. This paper examines how the Dominican Ministry of Education (MINERD) frames TPD, and how this conception reinforces teachers' professional status quo. It argues that MINERD should restructure the current TPD model to incorporate the teacher Community of Learning framework. This approach promotes teachers' continual learning by encouraging the performance of professional activities responsive to everyday, culturally situated classroom and school realities.
\end{abstract}

\section{Introduction}

For two decades, Dominican educational reformers have made a commitment to offer preservice education to Dominican teachers [48], [40], [49]. Less effort, however, has been dedicated to building well-designed in-service teacher education [40], [49]. In this paper, I put forward the idea that many pre-service education programs inadequately connect theory and practice, building from the work of scholars like Korthagen et al. [41]; and argue that pre-service education programs do not sufficiently equip teachers with the necessary knowledge and skills to support them throughout their career [35], [50]. Since the 1990s, research on teaching has increasingly focused on the impact of Teacher Professional Development (TPD) on teaching and

students' learning process [43]. Findings indicate that well-designed TPD improves teaching quality, helps teachers to design effective learning experiences [49] and bridges the gap between theory and practice in pre-service education programs [35]. While it is understood that professional development plays a pivotal role in enhancing the quality of teaching and teachers' professional growth, the Dominican Republic Ministry of Education (MINERD) has assumed an educational in-service model that yields unsuccessful results [40], [41]. By overlooking how teachers learn during their career and the important role of effective TPD on teacher improvement, MINERD perpetuates a depressed quality of teaching and learning. Hence, this paper will highlight the need for change in Dominican inservice education, which is defined here as the traditional model of off-site, fragmented workshops facilitated by external entities. It proposes Communities of Learning (CLs) as a potential solution, whereby Dominican teachers engage in a school-based, systematic, and autonomous educational process to optimize their instruction.

This literature review is structured to address the following questions:

1. What are the characteristics of traditional TPD in the DR?

2. What are the implications and effects of traditional teacher professional development in the DR as informed by broad review of the literature?

3. How might a Community of Learning (CL) perspective improve teacher in-service learning in the Dominican public sector based on teacher professional development research?

In examining the influence of the traditional TPD approach on teachers' professional learning, it is my objective to ignite a dialogue about its negative effects. I argue that measures taken by MINERD regarding teacher in-service education are unfruitful and hinder professional growth [1], [40], [49]. For instance, Dominican public schoolteachers perceive discouragement and lack of engagement with their profession, in part as result of the neglectful attitude of educational authorities toward sustaining an ineffective TPD model throughout the years [40]. I 
also highlight the potential role of MINERD in considering the Community of Learning paradigm as a potential approach that challenges the effects of the existing TPD and enacts authentic professional growth in teachers [51], [44], [50].

Throughout this paper, I develop my contention using the research on TPD and the international reviews of the DR educational system. I establish a link between the accounts of these publications about Dominican teacher professional development and the research findings concerning the model of TPD adopted by the DR. Finally, I draw from research on TPD to recommend that MINERD consider enacting school-based Communities of Learning.

\section{Rationale and Significance}

Teachers are the most important factor in any educational reform [35], [43]. Even under adverse educational system conditions, their quality impacts all aspects of learning environments [35], [39]. As scholarship indicates, teachers are catalysts for improving students' performance and promoting positive change in the classroom [4]. Similarly, Darling-Hammond [8] asserts that students' attainment is directly related to teachers' performance. In addition, researchers have identified a high correlation among quality education, qualified teachers, and students' attainment; therefore, teachers' development is pivotal to create environments that foster students' development and engage them in learning the expected academic skills [39]. Particularly now, with the world changing as rapidly as it is and new knowledge expectations for $21^{\text {st }}$-century citizens, teachers need to be able to teach competencies and academic skills adequate to this new technological environment and its challenges [11], [54]. Understanding teachers' responsibility in education, researchers have focused on understanding how teachers learn and improve their instruction [11], [39]. Findings indicate that teaching is a lifelong learning profession [9] and that meaningful qualified activities are fundamental to fostering this ongoing knowledge [6].

Teachers' continual learning does not come naturally [9] and teacher expertise is achieved when they learn through systematic and effective inservice activities [35], [48], [39]. Scholars' findings illustrate that successful learning activities are the ones which (a) lead teachers to effectively educate students in their specific social and cultural contexts, (b) help teachers shift certain preconceptions and beliefs about teaching, and (c) work collaboratively with colleagues [35], [43]. As Avalos [1] indicates, TPD is "about teachers learning, learning how to learn, and transforming their knowledge into practice for the benefit of their students' growth" (p.10). This concept widely differs from the commonly adopted traditional TPD model or "factory model," where teachers participate in workshops without the resources for learning in context, ultimately showing to be inadequate to enact teachers' learning [44], [48].

In bringing the DR to this discussion, it is important to acknowledge that MINERD is aware of teachers' crucial role in student performance, and that since the 1990s, it has prioritized TPD in its teacher education agenda. Beginning in 1992, the DR started the most significant educational reform in 40 years with the Ten Year Educational Plan: 19922002 [40]. One of the goals of this plan was to build a qualified teaching force by assuring that all teachers acquire a degree in education [44], [41], [49]. Complementary to this policy, many universities and institutions provided professional development modules [40]. However, outside evaluation of the policy has shown that instruction was not enhanced, and that there were still ongoing challenges regarding teachers' performance [36], [40], [49]. Moreover, further reports showed that teacher education alone is insufficient to address this problem and emphasized the need of providing inservice training [48], [36], [40]. These reviews informed MINERD's authority and prompted the adoption of new strategies including the United Nation Millennium Development Goals, Strategic Education Development Plan 2003-2013, and the second Ten Year Plan: 2008-2018 [36], [40]. Additionally, more recognized institutions, such as private universities and international agencies, continued to offer in-service training as a means of TPD [40]. However, these well-intended strategies have only slightly impacted the quality of Dominican teacher professional learning [1], [35], [41].

In a growing globalized and competitive world, the DR seeks to reduce the poverty gap, both within the country and between the DR and more affluent countries [48]. Qualified teachers are critical to an education system that counters the inherent problems of the Dominican low-income demography (e.g., social exclusion, unemployment) [1], [48], [40]. In this sense, I acknowledge that the failure of enacting teachers' learning and improvement may be caused by the insufficient attentiveness to research about TPD, in conjunction with a lack of discussion and evaluation of the in-service training established throughout the last two decades [48], [36]. In our current era of expanding knowledge, high-tech economy, and increasingly competitive job market, it is important that MINERD carefully reformulate its resolutions regarding in-service teacher education and urgently promote effective professional activities that lead to high quality education. By doing so, MINERD will be able to attain a higher level of equity among Dominicans, promoting a society which is able to progress financially, as well as ethically, and more ultimately helping transform the 
DR into a country that contributes to the overall world's development.

\section{The Teaching Profession in the Dominican Republic (DR)}

The DR, like many countries in Latin America, faces substantial challenges in providing teacher education that ensures high quality instruction [35]. In the DR, there are approximately 67,000 teachers, $74 \%$ of whom work for the public sector [35], [40], [41]. Moreover, in the DR, the teaching profession lacks a strong reputation and social esteem because of underpayment relative to other professions and the commonly adverse working conditions. For example, public education teachers might work under inadequate infrastructure, with lack of resources and overpopulated classrooms, and without effective preparation and induction [44], [40]. Regardless of these unfavorable conditions, there is still a vast population of young people, most from the rural areas, who become teachers. A high percentage of these candidates choose the profession, not by vocation, but because it guarantees a permanent job and enticing benefits (e.g., retirement pension, teachers union, promotion by seniority), which for many of these candidates represents the only vehicle to progress from their low-income social background [40]. As a result, the professional image of teachers is commonly portrayed by the particular conditions mentioned above and is perceived as extremely weak.

Along with the disadvantageous conditions and lack of social acceptance of the teaching profession, the two universities with the highest enrollment to prepare public teachers have inexpensive tuition, lack rigorous admission processes, and are characterized by deficient programs and insufficiently qualified professors [44], [40], [49]. This promotes the registration of candidates who possess a weak motivation for the profession and results in these universities functioning with an "open door" for whomever chooses to become a teacher [1], [41]. In summary, teaching has become an extraordinary opportunity for many to get a degree, which leads to better opportunities for many Dominicans with a low educational and cultural level [40], [49]. Hence, these universities continue to perpetuate the low-quality education that prevails in the DR.

The DR's public schools mirror the educational teaching force problems and social background described above. Approximately 50\% of the teachers have less than five years of work experience [40]; in a public school context, few teachers have the knowledge of content and practice that is a requisite in current measures of teacher quality [40], [49]. There is a lack of opportunities for teachers to advance within the profession; currently, teachers need only five years of well-reputed teaching to apply for managerial positions outside of education with better salaries and opportunities for decisionmaking [40], [41], [49]. This rotation of inexperienced teachers in the Dominican classrooms promotes an unstable environment in the schools and induces the best teachers who generally have better performance - due to professional vocation or better educational and household backgrounds - to seek career development outside the classroom [1], [49]. As a result, there is a shortage of qualified teachers in the classroom, leaving schools with a majority of novice teachers or teachers who are focused on obtaining their pensions through seniority [1].

A key trait of the Dominican public school system is that teachers are usually hired by shifts, an arrangement where classes occur in the morning, afternoon, and occasionally in the night. Originally, this system was established as part of a solution to the deficit of classrooms and teachers [36], [40]. In order to acquire an acceptable salary, teachers commonly worked two shifts [37]. As result, there was (a) a decrease of the legally constituted school schedule due to teachers and students mobility, (b) an overuse of school resources and infrastructure [40], [37], and (c) teacher weariness from teaching more than one group of students [36]. These undesirable consequences of the shift system, in conjunction with teachers' poor salaries, provoked the MINERD in its second Ten Year Plan: 20082018 to include the construction of classrooms and call for the abolishment the shift system, ultimately launching a full-time schedule with higher wedges for public teachers. During the last 5 years, MINERD has been progressively moving toward this goal and in the academic year 2013-2014, MINERD reported that 96 pilot schools have adopted the new full-time schedule, thereby benefiting approximately 33,000 students [36], [43]. This new policy of a full time schedule is significant when considering meaningful professional activities that could improve the quality of Dominican teachers, which I will develop later in this paper.

In the last five years, there has been an increasing dialogue among institutions in charge of teacher education, MINERD, and the Teacher Union. The objective of these conversations has been the adoption of new measures to improve the quality of teachers and promote teaching as an attractive professional career [38]. As result of this continued effort to increase the quality of teachers, MINERD, with the support of local and international organizations, also (a) developed new standards for teacher education and teachers' professional profile, and (b) established a new system of teacher evaluation based on competencies [38], [41]. In addition, 2012 saw the development of a national plan of teacher reform with the aim of strengthening the teaching profession [35], [51] through "designing 
an admission process to improve the quality of teacher candidates, elaborating a national plan to better educate teacher educators, accrediting teacher programs, establishing mentorship, and developing research on teacher education" [35]. Although there is this strong blueprint to develop quality pre-service education, there is still a lack of dialogue regarding teacher professional development [35].

Some Latin American countries-including Chile, Mexico, Brazil, and Costa Rica, which experienced a similar teaching profession context to the DR - have improved their teaching and students' learning by prioritizing effective TPD [35]. Looking at the data from these countries suggests that MINERD's current plan for teacher improvement, while well intentioned, could be seen as deficient because it overlooks the research on effective TPD, specifically teachers expanding their knowledge through a constant process of professional development based on classroom context [43], [35], [45], [48], [51], [50].

In this section, I have discussed the less than desirable image of the teaching profession in the DR, the motivational factors at play in becoming a teacher, the social and cultural background of teacher candidates, and the role of some public universities in providing low-quality education to many of the Dominican teacher candidates. I have also highlighted some of the challenges the DR faces regarding the profession, including improving the overall quality of teaching and reducing the high attrition of experienced and qualified teachers within the school classroom. I have indicated that the current endeavors of the DR to improve pre-service teacher education could result in deficient measures, because there is a lack of dialogue to develop effective TPD. Indeed, I have put forward that effective teacher professional development is a potential vehicle to achieve quality in teaching and learning in the DR. As mentioned previously, the role of TPD is an extremely important piece of any discussion concerning teacher education, and will be further developed in the next section of this paper with a focus on TPD in the DR.

\section{Implications and Effects of Traditional Workshops}

The DR established a system of professional workshops delivered by private institutions (e.g. universities, international organizations) within the framework of the educational reform Ten Year Plan: 1992-2002 with the goal of improving teaching quality [40]. In addition to these trainings, another major policy implementation was the creation of the National Institute of Teacher Education and Training (INAFOCAM): a decentralized institution, in 2001, with one of its main functions being to regulate and provide in-service education nationwide [40], [41].
However, INAFOCAM function has been limited to managing the recruitment of workshop facilitators, and supporting and following up on the professional programs designed by the other institutes [40]. Therefore, in the DR, the prevailing system has evolved in such a way that local and international organizations coordinate, provide, and fund numerous off-site in-service workshops for the public teachers [44], [40], [41].

Although the funding and support of external entities may seem like a significant help to the educational system, reports on Dominican in-service training show that TPD has been deficient in a number of ways: (a) it has not improved teaching and learning; (b) it has not supported the consideration of diversity among educators and in school contexts; (c) it has provided insufficient articulation between the pre-service education and the content disseminated in workshops; and (d) there seems to be a lack of coherence between the course content and school conditions to support delivering teaching methods and learning models [1]. The failure of these inservice trainings is typically attributed to: (a) lowquality pre-service education [35], [41], [48]; (b) a lack of strong policy for in-service education; and (c) inconsistent evaluation of the professional workshops [40]. However, in my view, another potential cause could be that MINERD authorities are overlooking the ways in which teachers learn and develop and, in the process, failing to create a fruitful model of systematic professional learning. Consequently, these trainings have fell short in meeting their objective of enacting teachers' learning and improving the quality of the Dominican educational system.

These negative findings regarding the workshops that have been developed in the Dominican context should come as no surprise, as they generally adhere to the traditional TPD model. Research shows that traditional TPD - which consists of fragmented, offsite workshops delivered by individuals who are not related to the school contexts - is not an adequate tool to improve teaching [48], [45], [50]. While older research tended to assume that professional development workshops were an effective tool for improving the quality of teaching and learning, a new body of research shows that teachers learn better when they participate in ongoing formation through shared practice connected to their specific cultural and pedagogical context [45], [48], [51]. Therefore, I argue current TPD practices, based on the aforementioned traditional TPD model, reinforce Dominican teachers' professional status quo.

\section{Communities of Learning (CLs)}

As discussed in the previous section, traditional in-service education workshops - the current TPD structure sustained by MINERD for more than two 
decades - are not recommended for enhancing teacher professional growth [42], [45]. Instead, research on teaching has increasingly discussed how Communities of Learning (CLs), "ongoing groups of teachers ... who meet regularly for the purposes of increasing their own learning and that of their students" [13, p.2], offer an effective alternative for enacting professional growth by promoting collaboration among colleagues and contextualized learning opportunities [44], [43], [35], [45], [48], [51], [44], [50].

Another feature of a CL is the community leader, who is charged with supporting his or her colleagues in this educational venture. In discussions regarding a CL leader, some scholars refer to the principal as the leader of a CL [44]. Other academics, however, show that teachers' unwillingness to assume leadership roles is sometimes caused by the prevailing "bureaucratic" and "hierarchical" structure of the school system $[15, \mathrm{p} .10]$; thus, many teachers perceive that all decision-making and control lies in managerial positions and is not within their own control [49]. Acknowledging this, some scholars argue that the CL should be a qualified teacher who ignites constructive dialogue regarding teaching and learning [48].

In order to promote the flow of new information and practical knowledge, a CL should be open to the wider professional networks and courses. McLaughlin and Talbert show that there are effective forums for teachers' learning outside of school courses [51]. This idea might seem contradictory to the previous discussion on teachers' learning in school and classroom contexts. However, McLaughlin and Talbert explain that they are not referring to pre-packaged and decontextualized workshops, but to socialization with other teacher networks and courses that serve as a "catalyst and support for the instructional improvement in a teacher community" [19.p. 65). Therefore, one of the main differences between effective and ineffective outside of school courses lies in the learning environment of the course. Effective outside of school courses provide teachers with opportunities to network with colleagues and connect their learning to the larger conversation occurring within their CL. Considering this finding, professional networks and well-designed courses could be used to bolster the professional learning within a CL.

The Dominican educational system does not enjoy an in-service education with the learning environment described above [35]. Based on the account of the aforementioned research, I argue that by adopting a community-based model of professional development, the Dominican teachers may optimize teaching and learning. I also suggest that the role of a teacher leader (TL) within a CL could provide new opportunities for leadership within the Dominican school contexts. Furthermore, the construction of this teacher community paradigm in the DR may be fostered by professional networks and courses that work in conjunction with the CLs.

\subsection{Teacher leaders (TLs) within Communities of Learning (CLs)}

As previously discussed, research shows that teachers learn effectively by participating in longterm CLs. However, fewer scholars draw attention to the importance of the role of a teacher leader (TL) to sustain a CL [21], [45], [46]. Effective teacher leaders (TLs) are expert teachers who are able to "deconstruct their practice, explain it to others, and in the process learn how to facilitate learning for (and with) their peers" [14, p.460]. Similarly, Heikkinen et al. [21] describe the role of a TL as a "confidence builder" (p.12), who mentors and supports the professional growth of his or her colleagues. According to these definitions, it is the role of a TL to promote an effective learning environment that sustains the shared practice over time, and to scaffold his or her peers' knowledge, when necessary. In their study of TLs in CLs, Lieberman and Friedrich [35] found that TLs develop their leadership skills by acquiring an "identity" as teacher-leaders, building "collegiality", "making conflict productive", and "reflecting on new and old knowledge to learn from practice" (p.5). By assuming this role, qualified teachers develop new skills and a professional identity that contributes in a different manner to their own professional development.

Lawrence and Chong [26] also conducted research on a lesson study group in Singapore. Their work found that younger members benefited from the expertise of "experienced teachers" (p.469), and other knowledgeable teachers were able to learn new skills and views about teaching. The study also pointed out that teachers acknowledged the need for qualified colleagues who can provide them with specific knowledge to improve their lesson planning. Similarly, Avalos [2] described recent policies in Chile aimed at enabling "highly competent teachers" (p.391) to assume the role of "professional developers" (p.391) inside a teacher community. The role of the "pedagogista" in the Reggio Emilia early childhood approach provides another example; one of the pedagogista's responsibilities is to support teachers' work by helping them engender new ideas and learning experiences, reflect on their practice, and improve in children's observation and documentation [14]. Comparable to the pedagogista in Reggio Emilia, Fullan and Knight [15] describe the work of the coaches in Canada, who are adept educators helping in teachers' networks to improve instruction, lesson planning, and evaluation. These teacher leadership models from international educational systems stress the key role of a TL to 
support colleagues toward their communal goal of enhancing teaching and increasing student learning.

Other research suggests that qualified teachers should be educated to assume this role. According to Heikkinen et al. [21], in Finland, mentors who support peer-coaching groups train for an academic year to learn tools and theory related to group guidance and cooperative working techniques, including creating an environment "without performance pressure" (p.28). Similarly, in their research in Logan City, Australia, Kearney and Zuber-Skernit (2012) studied communities of practice to empower low-income immigrants to solve issues regarding their surroundings. For eight months, ten members were trained in leadership skills in order to become the community leaders. Results showed the leaders were able to promote learning environments and support members in solving their main problems. Harris [19] adds that enabling leadership inside the community "will not be achieved by clinging to models of leadership that, by default rather than design delimits the possibilities for teachers to lead development work in schools" ( $p$. 322). Distributing the leadership within the school context and preparing teaching staff to develop leadership skills fosters trusting relationships, and more ultimately an effective learning culture. As the research previously discussed shows, a TL is not about being a pundit, but instead dedicated to creating a successful, participatory learning culture.

5.1.1. TLs within CLs: Implications for the DR. International agencies' reviews of the Dominican educational system suggest that another cause of the deficient teaching force in the public sector is related to the exodus of the best teachers from the classroom to assume managerial roles (e.g., superintendent, school director, regional technician) in order to acquire higher salaries and participate in decisionmaking processes within the schools [40], [49]. Together with providing a platform to transform TPD to CLs, MINERD should explore new forms of educational leadership in order to retain the few qualified teachers within the classroom. Extending this idea further, I suggest that along with increased pay, the role of TLs inside the CLs could serve to boost the best teachers' satisfaction and permanence within the classroom. TLs would be given the opportunity to make choices, otherwise known as human agency, within their profession, enabling them to act as a support base for teachers in a learning culture for the benefit of Dominican students.

Abréu -Van Grieken [1] also explains how seniority is still rewarded more than teaching skills and competencies in the DR. As a result of this, teachers' motivation to reach expertise or excel in the teaching profession is suppressed. A TL within a $\mathrm{CL}$, in the Dominican context, could serve (a) as a role model to inspire colleagues to be better professionals; (b) to promote an environment inside a CL where teachers support each other in developing the expected skills established in the recent teacher evaluation by competency policy; (c) and to have a less bureaucratic school system, promoting a linear communication between principals and teachers. In summary, I recommend that a TL within a CL, in the $\mathrm{DR}$, could serve as agent for transforming schools into learning organizations, ultimately promoting students' success.

\subsection{Courses and Teachers' Networks for a CL}

In conjunction with enabling TLs, the CL should be open to other sources of knowledge beyond the school setting [35], [51], [44]. According to McLaughlin and Talbert [51], "insulation for the broader professional network will stymie the improvement efforts of even the most engaged and collaborative teacher community" (p.64). In order to expand and strengthen knowledge, members of a CL should take advantage of the incessant production of knowledge, resources, and learning experiences available in the nation-wide and international educational community. Unlike the traditional TPD workshops, McLaughlin and Talbert [51] describe "off-site professional development (OSPD)" as "high-quality" (p.65) learning experiences focused on reviewing, reconsidering, and deepening participants' knowledge and practice. This new knowledge is then to be shared with the rest of the community, adapting it to the school context, and bringing new and fresh perspectives to the members of the CL.

Through a weeklong summer course of HighSchool teachers, McLaughlin and Talbert [51] highlight the relationship between OSPD and a CL. Their work establishes a clear link between OSPD and scaffolding of a CL. It suggests that these courses provide teachers with the tools to improve and sustain their CL. McLaughlin and Talbert [51] also recognize that OSPD provides teachers with opportunities to observe teachers from other contexts collaborating, working, and implementing together. Through such courses, teachers are able to network and learn about a topic of interest that could enrich and improve their school-based CL. DarlingHammond et al. [43] described Singapore's 1998 educational reform as having the objective of establishing schools as learning environments. Program components included "learning circles, teacher-led workshops, and conferences" (p.17). These initiatives were also supported by the National University, which trained teachers on "reflection, dialogue and action-research" (p.17). Teachers' new knowledge in the off-site courses was constantly applied in the school-based learning circles, enabling 
teachers to "produce knowledge and not just disseminating received knowledge" (p.17). These examples suggest the potential of CLs to improve the quality of teaching, through thoughtful off-site learning experiences that help teachers to answers questions that are beyond their context, complementing their professional learning and strengthening their school-based CL.

In addition to incorporating OSPD, a CL should establish connections with other teacher networks [23], [45]. In their study of 40 secondary teachers in England, James and McCormick [23] show the benefits of networking across schools. These include generating new knowledge and promoting professional growth inside a CL. Similarly, Jackson and Temperley [22], argue that "school-to-school collaboration" (p.45) is essential to reduce the achievement gap and develop teachers' learning. They studied the Networked Learning Communities (NLC) in England, which had the primary purpose of improving the quality of the educational system. Results show that when teachers are connected with other educational networks, four types of learning were generated: "learning from one another", "learning with one another", "learning on behalf of", and "Meta-learning" (p.49). They found that teachers also developed and strengthened their professional identities and instruction. Likewise, Thornton and Brunton [47] explain the successful role of the Preschools and Infant-Toddler Centers Institution in Reggio Emilia, which role is to connect the early childhood schools. This institution promotes the early childhood professional network, supporting and guaranteeing ongoing teacher learning and the quality of the children's' experience. Considering these findings, it is important that a CL maintain contact with widespread educational networks to assure the constructive interchange of ideas.

5.2.1. Courses and teachers' networks for a CL: Implications for the DR. The previous discussion illustrates the ways in which external sources, such as off-site courses and professional networks, can be used to support teachers' professional growth when incorporated into the context of a CL. This is an extremely important piece for the DR because there is absence of teacher networks [1], [18]; and more frequently, teachers might have access to seminars, masters' degree programs, and conferences financed by INAFOCAM and other institutions [41]. However, these programs, as traditional workshops, usually have a top-down approach, do not take into account teacher context and school conditions, and do not promote collaborative learning [18]. In light of this, it is imperative to understand that any attempt to promote teacher learning using a factory model approach will be unsuccessful for the reasons previously discussed. Although there is omission of the CL paradigm in Dominican public schools, if
MINERD did decide to promote effective in-service education and construct this approach of TPD, external entities' support should be focused on helping teachers to (a) collaboratively learn based on their local needs; (b) develop tools that will have applicability to their realities; and (c) build teacher networks.

Many scholars claim that the vast majority of Dominican public teachers lack the basic content knowledge to teach and that it is necessary to support them in this important aspect of teaching [1], [40], [41]. I agree that this is of primary concern for Dominican public school teachers, but am hopeful that the latest blueprint to improve pre-service education will result in improved teacher preparedness in this area. Examined research also shows that pre-service education fails to equip teachers for lifelong learning and continual improvement, but that effective TPD is an essential component of teachers' progress and subject matter understanding. Hence, the funding for external entities' and resources could be reallocated to support teacher professional growth within a system of school-based CLs and also to develop wellintegrated OSPD courses. The latter, as research suggests, should (a) be built on a curriculum that is relevant to teachers' local context; (b) lead teachers to learn how to teach their subject matter and apply the strategies within their classroom circumstances; (c) instruct them on how to work systematically and collaboratively with colleagues; and (d) promote the use their cultural capital and local knowledge to design learning experiences that are relevant for them and also for their students. I find this idea of an integrated TPD framework to hold great promise for the DR; thus, I suggest that CLs be established with careful consideration given to the current initiatives designed to improve Dominican education, OSPD courses, and teacher networks. These external sources can be effectively integrated into CLs to build a unified and sustainable system of TPD for the DR.

In this section, I have discussed how the CL framework can serve as a successful model for TPD. Specifically, I have addressed the benefits of a CL, the role of a TL within it, and the function of welldesigned courses and teacher networks in sustaining a CL. After reviewing the research on CLs, I have linked the findings of this body of literature to the Dominican School system to suggest the incorporation of this paradigm in the educational context. Finally, I have emphasized that Dominican teachers' professional growth could be improved if MINERD were to innovate with school-based CLs.

\section{Conclusion}

Educating qualified teachers is one of the biggest challenges in the Dominican Republic, and has been 
one of the main priorities of educational reform in the last 20 years. Nevertheless, these reforms have consistently addressed what teachers should learn, instead of generating a dialogue to understand how teachers learn. In the Dominican Republic, professional development for teachers is implemented through fragmentary workshops that (a) follow a fixed curriculum designed and delivered by external entities (b) outside of the school context.

Republic Ministry of Education (MINERD) has traditionally supported and promoted these workshops, research on teacher professional development suggests that this approach is not successful in developing teacher learning. It refuses to conceptualize teachers as active learners and fails to provide a systematic process for questioning preconceptions about instruction and linking theory to practice. Based on this, I argue that MINERD is sustaining an inadequate model of TPD and I urge MINERD to examine its current structures for teacher professional development. Failure to reconsider these structures may hinder teachers' professional growth and reinforce the current professional conditions for teachers, negatively impacting student outcomes.

Complimentary to the previous argument, research on TPD indicates that teachers learn better in their profession through socialization, reflection, and finding solutions for the particular needs of their students. In this sense, I bring awareness to that fact that teachers become experts through a long-term process of continual learning that extends far beyond periodic workshops. I emphasize that school-based Communities of Learning (CLs) could serve as a framework to transform Dominican in-service education.

Furthermore, I contend that MINERD can achieve their desired goal of improving the quality of teaching by (a) building structures to establish collaborative professional activities within the school context; (b) creating new forms of leadership within a CL; and (c) using the available funding and existing external support to help teachers succeed in their particular context within a CL.

The enactment of successful professional activities requires that MINERD redesign and implement effective policies to support authentic teacher professional growth. Changing the TPD paradigm might generate stakeholder conflicts; however, if MINERD does not take bold action to improve the structure of TPD, the professional status quo in the teaching force will persist. Teacher professional growth does not occur through prepackaged instruction delivered by external entities, but by empowering teachers to link theory with practice. Teacher in-service education must be an imperative piece of the conversation around Dominican education: it is time that teachers have the opportunity to learn effectively and positively impact Dominican pupils.

\section{Reference}

[1] Abréu-Van Grieken, C. (2012). Career notes for teachers in Dominican Republic. Ciencia y Sociedad, 37(4), 387-400.

[2] Avalos, B. (2010). Educational change in Chile: reform or improvements? 1990-2007. In M. Fullan, A. Hargreaves, A. Lieberman, \& D. Hopkins (Eds.), Second International Handbook Of Educational Change (pp. 383396). Dordrecht: Springer.

[3] Avalos, B. (2011). Teacher professional development in teaching and teacher education over ten years. Teaching and teacher education, 27(1), 10-20.

[4] Bakkenes, I., Vermunt, J. D., \& Wubbels, T. (2010). Teacher learning in the context of educational innovation: Learning activities and learning outcomes of experienced teachers. Learning and Instruction, 20(6), 533-548.

[5] Beca, C. (2012). Informe final sobre consultoría sobre política docente en Republica Dominicana. Publicaciones de la OEI. Retreived from

http://www.minerd.gob.do/idec/Docs2/4http://www. minerd.gob.do/idec/Docs2/4

[6] Borko, H. (2004). Professional development and teacher learning: mapping the terrain. Educational Researcher, 33(8), 3-15.

[7] Clausen K. W., Aquino, A. M., \& Wideman, R. (2009). Bridging the real and ideal: A comparison between learning community characteristics and a school-based case study. Teaching and Teacher Education, 25(3), 444452 .

[8] Darling-Hammond, L. (1998). Teacher learning that supports student learning. Educational Leadership, 55(5), 6-11.

[9] Darling-Hammond, L., \& Sykes, G. (1999). Teaching as the learning profession: Handbook of policy and practice. San Francisco: Jossey-Bass

[10] Darling-Hammond, L., \& Bransford, J. (2005). Preparing teachers for a changing world: What teachers should learn and be able to do. San Francisco: Wiley

[11] Darling-Hammond, L. (2006). Constructing 21stcentury teacher education. Journal of Teacher Education, $57(3), 300-314$.

[12] Darling-Hammond, L., \& Richardson, N. (2009). Research review/teacher learning: What matters. Educational Leadership, 66(5), 46-53.

[13] Education International Latin America. (2009). Teacher Training in Latin America: Report on Case Studies in Chile, Nicaragua, Peru and The Dominican 
Republic. Education International. San Jose: Outdanning Forbunded.

[14] Filippini, T. (1998). The role of the pedagogista. In C. Edwards, L. Gandini, \& G. Foreman (Eds.),

The hundred languages of children: The Reggio Emilia approach-Advanced reflections (pp. 27-137) Westport: Ablex Publishing Corporation.

[15] Fullan, M., \& Knight, J. (2011). Coaches as system leaders. Educational Leadership, 69(2), 50-53.

[16] Gajardo, M. (2007). Dominican Republic country case study: Country Profile. Commissioned for the EFA Global Monitoring Report 2008, Education for All by 2015: will we make it?. Washington, DC: UNESCO.

[17] Garet, M. S., Porter, A. C., Desimone, L., Birman, B. F., \& Yoon, K. S. (2001). What makes professional development effective? Results from a national sample of teachers. American Educational Research Journal, 38(4), 915-945.

[18] Guzman, J.L., Castillo, M, Lavarreda, J, \& Mejía, R. (2013) Effective Teacher training policies to ensure effective schools: A perspective from Central America and the Dominican Republic. In International Conference for School Effectiveness and Improvement (ICSEI 2013).

[19] Harris, A. (2003). Teacher leadership as distributed leadership: Heresy, fantasy or possibility? School Leadership and Management, 23(3), 313-324.

[20] Hawley, W., \& Valli, L. (1999). The Essentials of Effective Professional Development: A New Consensus. In L. Darling-Hammond, \& G. Sykes (1999). Teaching as the learning profession: Handbook of policy and practice ( $p p$. 127-150) San Francisco: Jossey-Bass

[21] Heikkinen, H. L., Tynjälä, P., \& Jokinen, H. (Eds.). (2012). Peer-group mentoring for teacher development. Routledge. New York: Routledge.

[22] Jackson, D., \& Temperley, J. (2007). From professional learning community to networked learning community. In L. Stoll \& K. S. Louis (Eds.), Professional learning communities: Divergence, depth and dilemmas (pp. 45-62). New York: Open University Press.

[23] James, M., \& McCormick, R. (2009). Teachers learning how to learn. Teaching And Teacher Education, 25(7), 973-982.

[24] Kearney, J., \& Zuber-Skerritt, O. (2012). From Learning Organization to Learning Community. The Learning Organizations, 19(5), 400-413.

[25] Korthagen, F. A., Kessels, J., Koster, B., Lagerwerf, B., \& Wubbels, T. (2001). Linking practice and theory: The pedagogy of realistic teacher education. New Jersey: Lawrence Erlbaum Associates, Inc., Publishers.

[26] Lawrence, C. A., \& Chong, W. H. (2010). Teacher collaborative learning through the lesson study: identifying pathways for instructional success in a Singapore high school. Asia Pacific Education Review, 11(4), 565-572.
[27] Lecrerc, I. (2012, August 23). La tanda extendida se aplicará en 96 escuelas. Listin Diario.

[28] Lieberman, A., \& Miller, L. (2008). Teacher in professional communities. New York: Teacher College Press.

[29] Lieberman, A., \& Pointer Mace, D. (2009). The role of 'accomplished teachers' in professional learning communities: Uncovering practice and enabling leadership. Teachers and Teaching: Theory and Practice, 15(4), 459-470.

[30] Lieberman, A., \& Friedrich, L. (2010). How teachers become leaders: Learning from practice and research. . New York: Teachers college Press.

[31] Lieberman, A., \& Miller, L. (2011). Learning Communities, The starting point for professional learning in schools and classrooms. Journal of staff Development, (32) 4 16-20.

[32] Little, J. W. (1995). Contested ground: The basis of teacher leadership in two restructuring high schools. The Elementary School Journal, 96(1) 47-63.

[33] Mangin, M. M., \& Stoelinga, S. R. (2008). Teacher leadership: What it is and why it matters. In M.M. Mangin \& S.R. Stoelinga (Eds.) Effective teacher leadership: Using research to inform and reform, (pp.10-35). New York: Teacher College Press.

[34] McLaughlin, M. W., \& Talbert, J. E. (2006). Building school-based teacher learning communities: Professional strategies to improve student achievement. NY: Teachers College Press.

[35] Mejía, R., Castillo, G., Portorreal, F., \& Vincent, M. (2006). El caso de República Dominicana. In D. Vaillant D. \& C. Rossel (Eds.) Maestros de escuelas básicas en América Latina. Hacia una radiografía de la profesión (pp. 187-214). Santiago de Chile: PREAL.

[36] Ministerio de Educación República Dominicana [MINERD]. (2008). Plan Decenal 2008-2018 (Ten Year Plan 2008-2018).

[37] Ministerio de Educación República Dominicana [MINERD]. (2012). Mesa de trabajo no.3 cumplimiento del calendario y el horario escolar.

[38] Ministerio de Educación Superior Ciencia y Tecnología [MESCYT], (2010). Plan de reformulación de la formación docente.

[39] Organisation for Economic Co-Operation and Development [OECD] (2005). Teacher Matters: Attracting, developing and retaining effective teachers. Paris: OECD.

[40] Organisation for Economic Co-Operation and Development [OECD]. (2008). Reviews of national policies for education Dominican Republic. Paris: OECD Publications. 
[41] Program for Educational Reform in Latin America and the Caribbean [PREAL], Educa, Plan. (2010) Pasando balance: Informe de progreso educativo: Republica Dominicana. Santo Domingo: PREAL, Educa, \& Plan.

[42] Snow-Gerono, J. L. (2005). Professional development in a culture of inquiry: PDS teachers identify the benefits of professional learning communities. Teaching and Teacher Education, 21(3), 241-256.

[43] Spillane, J. P. (2000). A fifth-grade teacher's reconstruction of mathematics and literacy teaching: Exploring interactions among identity, learning, and subject matter. The Elementary School Journal, 100(4), 307-330.

[44] Stoll, L., Bolam, R., McMahon, A., Wallace, M., \& Thomas, S. (2006). Professional learning communities: A review of the literature. Journal of Educational Change, $7(4), 221-258$.

[45] Stoll, L. (2010). Connecting Learning Communities: Capacity Building for Systematic change. In M. Fullan, A. Hargreaves, A. Lieberman \& D. Hopkins (Eds.), Second International Handbook Of Educational Change (pp. 469484). Dordrecht: Springer.

[46] Talbert, J. E., \& McLaughlin, M. W. (1993). Understanding teaching in context. In D. Cohen, M.W. McLaughlin, \& J. E. Talbert (Eds.), Teaching for understanding: Challenges for policy and practice (pp.167-206). San Franciso: Josssey Bass

[47] Thornton, L., \& Brunton, P. (2005). The organization of the pre-school and infant toddler center. In L. Thornton \& P, Brunton (Eds.) Understanding the Reggio approach (pp.18-31) London: David Fulton Publisher.

[48] United Nations Educational Scientific and Cultural Organization [UNESCO]. (2013). Education for all global monitoring report, policy paper 07. Paris: UNESCO.

[49] Vaillant, D., \& Cuba, S. (Eds). (2008). Profesion docenete en Latinoamerica: una agenda pendiente $y$ cuatro retos emergentes. Lima: GTD/PREAL

[50] Vescio, V., Ross, D., \& Adams, A. (2008). A review of research on the impact of professional learning communities on teaching practice and student learning. Teaching and Teacher Education, 24(1), 80-91.

[51] Vincent, M. (2012). Descripción Plan para la Reformulación de la Formación Docente en la República Dominicana. Metodología Comisión Interinstitucional para la Reformulación de la Formación Docente.

[52] Wagner, T. (2010). The global achievement gap: Why even our best schools don't teach the new survival skills our children need--and what we can do about it. NY: Basic Books. 